\title{
Iron oxide encapsulated in nitrogen-rich carbon enabling high-performance lithium-ion capacitor
}

\author{
Jinhua $\mathrm{Zhou}^{1 \dagger}$, Shuchi $\mathrm{Xu}^{1 \dagger}$, Qi Kang ${ }^{2}, \mathrm{Lu} \mathrm{Ni}^{1}$, Ningna Chen ${ }^{1}$, Xiaoge $\mathrm{Li}^{1}$, Chunliang $\mathrm{Lu}^{3}$, \\ Xizhang Wang, Luming Peng ${ }^{1}$, Xuefeng Guo ${ }^{1}$, Weiping Ding ${ }^{1}$ and Wenhua Hou ${ }^{1^{*}}$
}

\begin{abstract}
Lithium-ion capacitors (LICs) could combine the virtues of high power capability of conventional supercapacitors and high energy density of lithium-ion batteries. However, the lack of high-performance electrode materials and the kinetic imbalance between the positive and negative electrodes are the major challenge. In this study, $\mathrm{Fe}_{3} \mathrm{O}_{4}$ nanoparticles encapsulated in nitrogen-rich carbon $\left(\mathrm{Fe}_{3} \mathrm{O}_{4} @ \mathrm{NC}\right)$ were prepared through a self-assembly of the colloidal $\mathrm{FeOOH}$ with polyaniline (PANI) followed by pyrolysis. Due to the well-designed nanostructure, conductive nitrogen-rich carbon shells, abundant micropores and high specific surface area, $\mathrm{Fe}_{3} \mathrm{O}_{4} @ N C-700$ delivers a high capacity, high rate capability and long cycling stability. Kinetic analyses of the redox reactions reveal the pseudocapacitive mechanism and the feasibility as negative material in LIC devices. A novel LIC was constructed with $\mathrm{Fe}_{3} \mathrm{O}_{4} @ \mathrm{NC}-700$ as the negative electrode and expanded graphene (EGN) as the positive electrode. The wellmatched two electrodes effectively alleviate the kinetic imbalance between the positive and negative electrodes. As a result, $\mathrm{Fe}_{3} \mathrm{O}_{4} @ \mathrm{NC}-700 / / \mathrm{EGN}$ LIC exhibits a wide operating voltage window, and thus achieves an ultrahigh energy density of $137.5 \mathrm{~W} \mathrm{~h} \mathrm{~kg}^{-1}$. These results provide fundamental insights into the design of pseudocapacitive electrode and show future research directions towards the next generation energy storage devices.
\end{abstract}

Keywords: $\mathrm{Fe}_{3} \mathrm{O}_{4}$, carbon, $\mathrm{N}$ doping, expanded graphene, lithium-ion capacitor

\section{INTRODUCTION}

Electrochemical energy storage systems play a crucial role in consumer electronics, automotive, aerospace and sta- tionary markets. Lithium-ion batteries (LIBs) and supercapacitors (SCs) are currently recognized as two primary promising energy storage systems [1-3]. LIBs can provide a high energy density $\left(100-200 \mathrm{~W} \mathrm{~h} \mathrm{~kg}^{-1}\right)$ as a result of Faradaic reactions derived from the intercalation of large numbers of $\mathrm{Li}$ ions into the active electrode materials. However, the sluggish insertion/extraction of Li ions in the bulk and the accompanied volumetric strain limit their power density $\left(<500 \mathrm{~W} \mathrm{~kg}^{-1}\right)$ and cycling stability $<1000$ cycles). By contrast, SCs store charge by fast reversible redox reactions or adsorption/desorption on the surface or near-surface of the active materials, benefiting a high power density $\left(>10 \mathrm{~kW} \mathrm{~kg}^{-1}\right)$ and a long cycling stability $\left(10^{4}-10^{5}\right.$ cycles). Unfortunately, they generally suffer from low energy densities (usually $\leq 10 \mathrm{~W} \mathrm{~h} \mathrm{~kg}^{-1}$ ), because the charge is mainly stored on the surface or near-surface [4-7]. For practical applications in vehicle power storage systems and grid energy storage systems, special energy storage devices with high energy density, high power density and long cycle life are highly desired [8].

Lithium-ion capacitors (LICs) are designed to possess high energy density, high power density and long cycling stability, being a tradeoff between LIBs and SCs. An LIC is constructed with a high-energy LIB negative electrode and a high-power SC positive electrode in a Li-salt-containing organic electrolyte $[9,10]$. LICs asymmetrically and simultaneously store charges by reversible adsorption/desorption of anions on the surface of capacitor-type positive electrode and by insertion/extraction of $\mathrm{Li}$ ions in the battery-type negative electrode, respectively. With the combination of Faradaic intercalation and non-Faradaic

\footnotetext{
${ }^{1}$ Key Laboratory of Mesoscopic Chemistry of MOE, School of Chemistry and Chemical Engineering, Nanjing University, Nanjing 210023, China

2 Department of Polymer Science and Engineering, Shanghai Key Laboratory of Electrical Insulation and Thermal Aging, Shanghai Jiao Tong University, Shanghai 200240, China

${ }^{3}$ Analytical Testing Center, Yangzhou University, Yangzhou 225009, China

${ }^{\dagger}$ These authors contributed equally to this work.

* Corresponding author (email: whou@nju.edu.cn)
} 
surface reaction, the energy and power densities are improved effectively [11]. The LIC was first reported by Amatucci et al. [12-14], with $\mathrm{Li}_{4} \mathrm{Ti}_{5} \mathrm{O}_{12}$ (LTO) as the negative electrode and activated carbon (AC) as the positive one. Naoi et al. [15] prepared a nanocomposite by incorporating LTO with carbon nano-fibers as the negative electrode, leading to devices with higher energy density than conventional electrical double layer capacitors (EDLCs) without significant reduction of power capability and cycle life. However, the low capacities of LTO and AC greatly restrict the overall energy density of LIC. Therefore, more efforts have been focused on optimizing the electrode materials.

With regard to battery-type negative electrode, graphite [16] and metal oxides $\left(\mathrm{TiO}_{2}\right.$ [17], $\mathrm{MnO}$ [18], $\mathrm{Fe}_{2} \mathrm{O}_{3}$ [19], $\mathrm{Nb}_{2} \mathrm{O}_{5}$ [20], $\mathrm{V}_{2} \mathrm{O}_{5}$ [21], $\mathrm{MoO}_{3}$ [22], etc.) have been intensively investigated because of their high energy densities. As for capacitor-type positive electrode, carbonaceous materials (such as AC, carbon nanotubes (CNTs) [23], graphene [24], and metal-organic framework (MOF)-derived porous carbon [25]) are widely selected due to their long-term cycling stability and high power density. However, the negative kinetics based on the lithiation/delithiation in the bulk is generally slower than the positive surface or near-surface adsorption/desorption. The resulting kinetic imbalance between the two electrodes greatly inhibits the full energy utilization of battery-type negative electrodes [26]. In addition, an enlarged operating voltage window is usually obtained for LICs, which is significantly beneficial for the improvement of energy density, as the energy density is directly proportional to the square of voltage window [27]. Therefore, the rational design and preparation of suitable negative materials are imperative for the development of high-performance LICs.

Among various metal oxides, $\mathrm{Fe}_{3} \mathrm{O}_{4}$ is quite promising as the negative material in LICs for its advantages of high theoretical capacity $\left(926 \mathrm{~mA} \mathrm{~h} \mathrm{~g}^{-1}\right)$, relatively low voltage plateau, eco-friendliness, natural abundance and low cost $[28,29]$. Nevertheless, there are rare reports about the use of $\mathrm{Fe}_{3} \mathrm{O}_{4}$ in LICs, probably due to the poor rate performance and cycle stability, which mainly result from its low intrinsic electronic conductivity, severe aggregation and dramatic volume expansion during $\mathrm{Li}$ insertion [19,30-32]. Hence, to optimize the performance of LICs, the modification of $\mathrm{Fe}_{3} \mathrm{O}_{4}$ materials has become a crucial issue.

Carbon coating is regarded as one of the most efficient modification ways for preventing the aggregation and improving the performance of transition metal oxides. It can significantly enhance the electronic conductivity and improve the rate performance of electrode materials. Moreover, the formation of stable solid electrolyte interface (SEI) films on carbon surface can protect the inner active materials and maintain their high capacities [3335]. On the other hand, a number of battery-type transition metal oxides could exhibit electrochemical pseudocapacitive features through nanostructuring. The increased specific surface area and shortened ion diffusion path lead to the improvement of high-rate capability and the suppression of a phase transformation $[7,9,36]$.

Here, we first prepared $\mathrm{Fe}_{3} \mathrm{O}_{4}$ nanoparticles encapsulated in nitrogen-rich carbon $\left(\mathrm{Fe}_{3} \mathrm{O}_{4} @ \mathrm{NC}\right)$ through a self-assembly of the colloidal $\mathrm{FeOOH}$ with polyaniline (PANI) followed by pyrolysis. The influence of different pyrolysis temperatures on the electrochemical performances of the resulting samples was investigated. Due to the well-designed nanostructure, conductive nitrogenrich carbon shells, abundant micropores and high specific surface area, the obtained $\mathrm{Fe}_{3} \mathrm{O}_{4} @ \mathrm{NC}-700$ delivers a high capacity with a high rate capability and a long cycling stability. Kinetic analyses of the redox reactions reveal the pseudocapacitive mechanism and the feasibility as negative material in LIC devices. Then, an LIC was constructed by using $\mathrm{Fe}_{3} \mathrm{O}_{4} @ \mathrm{NC}-700$ as the negative electrode and expanded graphene (EGN) as the positive electrode. As these two electrodes are well-matched, the kinetic imbalance between them is greatly alleviated, giving rise to a wide operating voltage range (1.0-4.5 V). As a result, the as-prepared $\mathrm{Fe}_{3} \mathrm{O}_{4} @ N C-700 / / E G N ~ L I C$ delivers an ultrahigh energy density of $137.5 \mathrm{~W} \mathrm{~h} \mathrm{~kg}^{-1}$ at a power density of $275 \mathrm{~W} \mathrm{~kg}^{-1}$ and a high energy density of $39 \mathrm{~W} \mathrm{~h} \mathrm{~kg}^{-1}$ at a high power density of $8250 \mathrm{~W} \mathrm{~kg}^{-1}$ as well as a long-term cycling stability.

\section{EXPERIMENTAL SECTION}

\section{Materials synthesis}

\section{Preparation of the $\mathrm{Fe}_{3} \mathrm{O}_{4} @ \mathrm{NC}$ negative electrode}

The detailed synthesis process was described in our previous report [37]. First, the uniform $\mathrm{FeOOH}$ colloid aqueous solution was obtained by mixing $10 \mathrm{~mL}$ of $1 \mathrm{~mol} \mathrm{~L}^{-1} \mathrm{FeCl}_{3}$ and $30 \mathrm{~mL}$ of $0.2 \mathrm{~mol} \mathrm{~L}^{-1} \mathrm{HCl}$ in $300 \mathrm{~mL}$ deionized water and subsequently aged in a reflux system at $96^{\circ} \mathrm{C}$ for $1 \mathrm{~h}$. Then, $150 \mu \mathrm{L}$ of aniline was added into $20 \mathrm{~mL}$ of the above $\mathrm{FeOOH}$ colloid and stirred for several minutes at $3-5^{\circ} \mathrm{C}$, followed by adding $0.15 \mathrm{~mol}$ of ammonium persulfate $\left(\left(\mathrm{NH}_{4}\right)_{2} \mathrm{~S}_{2} \mathrm{O}_{8}\right)$ and kept stirred for $24 \mathrm{~h}$. The resulting suspension was washed with deionized water through centrifugation for several times to 
remove the residual acid until the supernatant reached $\mathrm{pH}$ 7. The resulting FeOOH@PANI was collected and dried at $60^{\circ} \mathrm{C}$ for $24 \mathrm{~h}$. Afterwards, FeOOH@PANI was calcinated at 600,700 and $800^{\circ} \mathrm{C}$, respectively, to obtain the $\mathrm{Fe}_{3} \mathrm{O}_{4} @ \mathrm{NC}$ samples in a quartz tube under highpurity $\mathrm{Ar}$ atmosphere for $3 \mathrm{~h}$ with a heating rate of $5^{\circ} \mathrm{C} \min ^{-1}$. The resultant samples are denoted as $\mathrm{Fe}_{3} \mathrm{O}_{4} @ \mathrm{NC}-600, \mathrm{Fe}_{3} \mathrm{O}_{4} @ \mathrm{NC}-700$ and $\mathrm{Fe}_{3} \mathrm{O}_{4} @ \mathrm{NC}-800$, respectively.

Preparation of the EGN positive electrode

Graphene oxide (GO) was synthesized by Hummers' method [38]: natural graphite flake (2 g, 99.8\%, Alfa Aesar Chemical Reagent Co.) and sodium nitrate $\left(\mathrm{NaNO}_{3}, 2 \mathrm{~g}\right)$ were mixed, and then sulphuric acid $\left(\mathrm{H}_{2} \mathrm{SO}_{4}, 46 \mathrm{~mL}\right)$ was added into the mixture in an ice bath. After that, potassium permanganate $\left(\mathrm{KMnO}_{4}, 6 \mathrm{~g}\right)$ was slowly added into the mixture solution in an ice bath and heated at $35^{\circ} \mathrm{C}$ for $90 \mathrm{~min}$ followed by adding water $(120 \mathrm{~mL})$ and stirring at $90^{\circ} \mathrm{C}$ for $20 \mathrm{~min}$. After reaction, hydrogen peroxide $\left(\mathrm{H}_{2} \mathrm{O}_{2}, 30 \mathrm{wt} \%, 6 \mathrm{~mL}\right)$ was added to remove the surplus $\mathrm{KMnO}_{4}$. A yellow precipitate was finally collected by centrifugation and vacuum dried at room temperature.

GO layers were intrinsically intercalated by molecules such as sulfuric acid and water during the synthesis process. The thermal shock would trigger a sudden volatilization of the intercalated molecules, resulting in a 50-100 times expansion along the thickness direction (caxis) $[39,40]$. Hence, EGN was obtained through the following steps: the tube furnace was heated to $1000^{\circ} \mathrm{C}$, and then GO powders were pushed into the heating zone for $10 \mathrm{~s}$ under argon atmosphere [41].

\section{Materials characterization}

The morphologies and structures of the obtained samples were characterized by using scanning electron microscopy (SEM, JEOL JEM-6300F) and transmission electron microscopy (TEM, JEOL JEM-2100F, operating at an accelerating voltage of $200 \mathrm{kV}$ ). X-ray diffraction (XRD) patterns were taken on a Philip-X'Pert X-ray diffractometer with a $\mathrm{Cu} \mathrm{Ka}$ radiation $(\lambda=1.5418 \AA)$. Fourier transform infrared (FT-IR) spectra were recorded using a Bruker model VECTOR22 Fourier transform spectrometer. X-ray photoelectron spectroscopic (XPS) measurements were carried out on an X-ray photoelectron spectrometer (Thermo Fisher Scientific, K-Alpha) equipped with a hemispherical electron analyzer (pass energy of $20 \mathrm{eV})$ and an $\mathrm{Al} \mathrm{Ka}(h v=1486.6 \mathrm{eV}) \mathrm{X}$-ray source. The thermogravimetic analyses (TGA) were car- ried out with a DTG-60 thermal analyzer. Raman spectra were collected on a thermal dispersive spectrometer using a $10 \mathrm{~mW}$ laser with an excitation wavelength of $532 \mathrm{~nm}$. Nitrogen adsorption/desorption isotherms were recorded on a Micromeritics ASAP 2020 sorption instrument, and the samples were activated under vacuum at $300^{\circ} \mathrm{C}$ for $6 \mathrm{~h}$ before testing.

\section{Electrochemical measurements}

The electrochemical performances of the obtained samples were investigated by using CR2032 coin cells.

For the half-cell testing, the coin cells were assembled in an argon-filled glovebox with $\mathrm{Fe}_{3} \mathrm{O}_{4} @ \mathrm{NC}$ and EGN used as working electrodes, lithium foil as the counter electrode, Celgard 2400 membrane as the separator and $1.0 \mathrm{~mol} \mathrm{~L}^{-1} \mathrm{LiPF}_{6}$ in a mixture of ethylene carbonate (EC) and dimethyl carbonate (DMC) (1:1 by volume), separately. Typically, the active material $\left(\mathrm{Fe}_{3} \mathrm{O}_{4} @ \mathrm{NC}-700\right.$ or EGN), conductive carbon black (Super P), and poly (vinylidene fluoride) (PVDF) were mixed in a weight ratio of 80:10:10 to form homogeneous slurry, and then coated on the current foils. After drying at $100^{\circ} \mathrm{C}$ for $12 \mathrm{~h}$, the coated $\mathrm{Cu}$ foil was punched into disks with a diameter of $12 \mathrm{~mm}$. The mass loading of $\mathrm{Fe}_{3} \mathrm{O}_{4} @ \mathrm{NC}-700$ was $\sim 0.8 \mathrm{mg} \mathrm{cm}^{-2}$ and that of EGN was $\sim 2.0 \mathrm{mg} \mathrm{cm}^{-2}$. The tab density of $\mathrm{Fe}_{3} \mathrm{O}_{4} @ \mathrm{NC}-700$ was $0.091 \mathrm{~g} \mathrm{~cm}^{-3}$ and that of EGN was $0.041 \mathrm{~g} \mathrm{~cm}^{-3}$. The galvanostatic charge-discharge (GCD) tests were measured with a LAND CT2001A battery test system. The cyclic voltammetry (CV) and electrochemical impendence spectra (EIS) measurements were carried out on a CHI660D electrochemical workstation (Chenhua, Shanghai).

Before constructing LIC, the $\mathrm{Fe}_{3} \mathrm{O}_{4} @ \mathrm{NC}-700$ was firstly pre-lithiated by dropping with $20 \mu \mathrm{L}$ of $1.0 \mathrm{~mol} \mathrm{~L}^{-1} \mathrm{LiPF}_{6}$ electrolyte and then directly contacting with a piece of lithium foil for $5 \mathrm{~h}$ in an Ar-filled glovebox. Then, a $\mathrm{Fe}_{3} \mathrm{O}_{4} @ N C-700 / / E G N$ LIC was constructed with the prelithiated $\mathrm{Fe}_{3} \mathrm{O}_{4} @ \mathrm{NC}-700$ as the negative electrode and EGN as the positive electrode. The areal mass loadings of $\mathrm{Fe}_{3} \mathrm{O}_{4} @ \mathrm{NC}-700$ and EGN were 1.2 and $1.9 \mathrm{mg} \mathrm{cm}^{-2}$ and the corresponding thicknesses were 17 and $50 \mu \mathrm{m}$ for $\mathrm{Fe}_{3} \mathrm{O}_{4} @ \mathrm{NC}-700$ and EGN, respectively. CV and GCD tests were performed on the CHI660D electrochemical workstation. The cell-discharge capacitance $\left(C_{\text {cell }}\right)$ and specific capacitance $\left(C_{\mathrm{s}}\right)$ of LIC were calculated with the following equations:

$C_{\text {cell }}=I t / \Delta V$,

$C_{\mathrm{s}}=C_{\text {cell }} / m$, 
time (s), $\Delta V$ is the voltage window $(\mathrm{V})$ and $m$ is the total mass (g) of the two electrodes. Energy density (E, $\left.\mathrm{W} \mathrm{h} \mathrm{kg}{ }^{-1}\right)$ and power density $\left(P, \mathrm{~W} \mathrm{~kg}^{-1}\right)$ were calculated through the following equations:

$P=\Delta V \times I / m$,

$E=P \times t / 3600$,

$\Delta V=\left(V_{\max }+V_{\min }\right) / 2$.

\section{RESULTS AND DISCUSSION}

\section{Characterizations of the $\mathrm{Fe}_{3} \mathrm{O}_{4} @ \mathrm{NC}$ negative electrode}

The morphology of the as-prepared $\mathrm{Fe}_{3} \mathrm{O}_{4} @ \mathrm{NCs}$ was investigated by SEM and TEM. All three $\mathrm{Fe}_{3} \mathrm{O}_{4} @ \mathrm{NC}$ samples show an overall look of many uniform nanoparticles bound to each other (Fig. S1). As shown in Fig. 1a-d, the as-prepared $\mathrm{Fe}_{3} \mathrm{O}_{4} @ \mathrm{NC}-600$ and $\mathrm{Fe}_{3} \mathrm{O}_{4} @ \mathrm{NC}-700$ exhibit a similar spherical morphology. According to the TEM images, the building blocks are nanoparticles with a diameter from 10 to $30 \mathrm{~nm}$ that are encapsulated and confined in the carbon nanoshells. In addition, high resolution-TEM (HR-TEM) image of $\mathrm{Fe}_{3} \mathrm{O}_{4} @ \mathrm{NC}-700$ shows the crystal lattice fringes with a $d$-spacing of $0.25 \mathrm{~nm}$ from the (311) plane of $\mathrm{Fe}_{3} \mathrm{O}_{4}$ (Fig. S2). The corresponding energy-dispersive $\mathrm{X}$-ray spectroscopy
(EDS) elemental mappings (Fig. S3) display a uniform distribution of $\mathrm{C}, \mathrm{N}, \mathrm{O}$, and $\mathrm{Fe}$ elements in $\mathrm{Fe}_{3} \mathrm{O}_{4} @ \mathrm{NC}$ 700. As the pyrolysis temperature increased to $800^{\circ} \mathrm{C}$, the obtained $\mathrm{Fe}_{3} \mathrm{O}_{4} @ \mathrm{NC}-800$ no longer maintained a wellregulated spherical morphology and the building blocks showed an increased average diameter of $50 \mathrm{~nm}$ (Fig. 1e, f).

As shown in Fig. 1g, all smaples show a broad XRD peak at $20^{\circ}-30^{\circ}$, originating from the (002) crystal planes of the PANI-derived carbon. The rest diffraction peaks are in good agreement with those of $\mathrm{Fe}_{3} \mathrm{O}_{4}$ (JCPDS \#190629). These results demonstrate the in-situ carbonization of PANI and transformation of $\mathrm{FeOOH}$ to $\mathrm{Fe}_{3} \mathrm{O}_{4}$ after pyrolysis in an inert atmosphere. TGA curves of the samples under an air atmosphere are shown in Fig. S4. All three $\mathrm{Fe}_{3} \mathrm{O}_{4} @ \mathrm{NC}$ composites can be observed with a rapid mass loss between 300 and $500^{\circ} \mathrm{C}$, corresponding to the oxidation and decomposition of the carbon in air. It follows that the amount of $\mathrm{Fe}_{3} \mathrm{O}_{4}$ is estimated to be $\sim 11$ wt.\% in the $\mathrm{Fe}_{3} \mathrm{O}_{4} @ \mathrm{NC}$ composites.

In order to investigate the existence form of carbon layer, Raman spectroscopy was adopted. As shown in Fig. 1h, all samples show two obvious Raman peaks around 1348 and $1586 \mathrm{~cm}^{-1}$, which correspond to the D and $\mathrm{G}$ bands of partially graphitized carbon, respectively
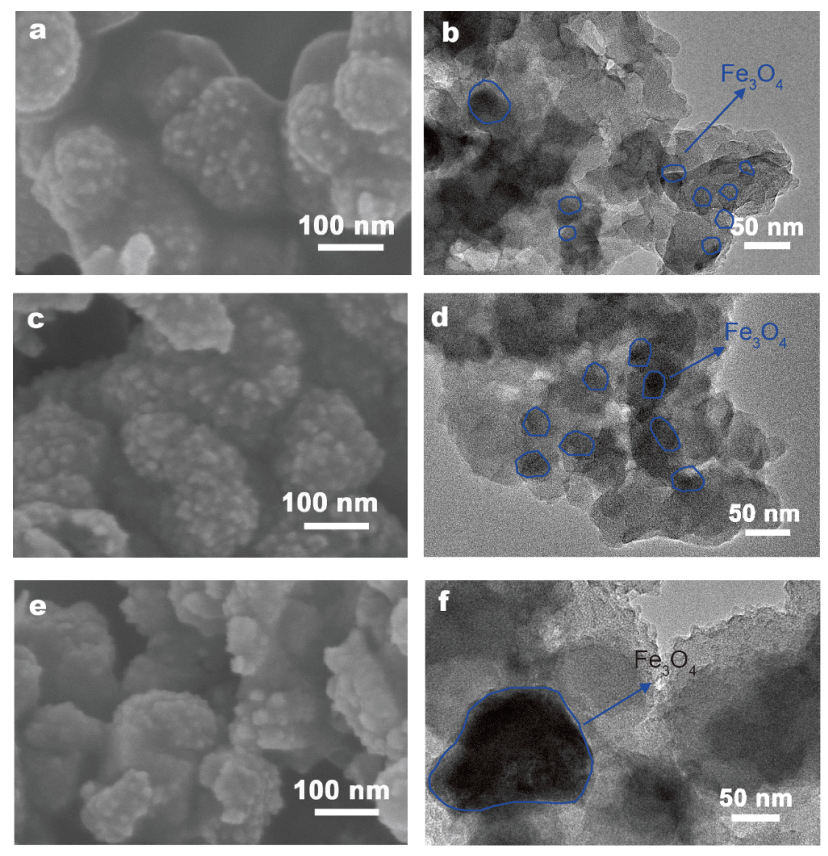
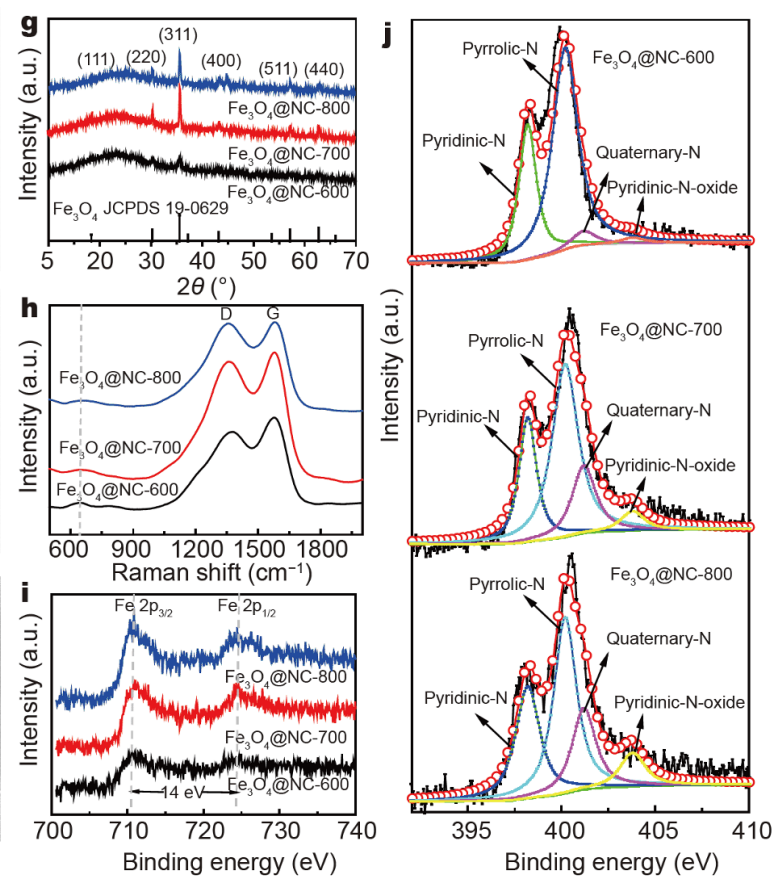

Figure 1 Morphological and structural characterizations of the $\mathrm{Fe}_{3} \mathrm{O}_{4} @ \mathrm{NC}$ samples with different pyrolysis temperatures. SEM (a, c, e) and TEM (b, d, f) images of $\mathrm{Fe}_{3} \mathrm{O}_{4} @ \mathrm{NC}-600(\mathrm{a}, \mathrm{b}), \mathrm{Fe}_{3} \mathrm{O}_{4} @ \mathrm{NC}-700$ (c, d) and $\mathrm{Fe}_{3} \mathrm{O}_{4} @ \mathrm{NC}-800$ (e, f), respectively. XRD patterns (g), Raman spectra (h), and highresolution Fe 2p (i) and N 1s (j) XPS spectra of the $\mathrm{Fe}_{3} \mathrm{O}_{4} @ \mathrm{NC}$. 
[20]. The intensity ratio of $\mathrm{G}$ band to $\mathrm{D}$ band $\left(I_{\mathrm{G}} / I_{\mathrm{D}}\right)$ can be used to estimate the graphitization degree of the carbon at different temperatures [42]. The values of $I_{\mathrm{G}} / I_{\mathrm{D}}$ are 1.10, 1.04 and 1.01 for $\mathrm{Fe}_{3} \mathrm{O}_{4} @ \mathrm{NC}-600, \mathrm{Fe}_{3} \mathrm{O}_{4} @ \mathrm{NC}-700$ and $\mathrm{Fe}_{3} \mathrm{O}_{4} @ \mathrm{NC}-800$, respectively. This result suggests that the graphitization degree slows down as the pyrolysis temperature increases. It may be caused by the defects of carbon due to the porous structure and $\mathrm{N}$-doping that are more easily formed at higher temperature [43]. In addition, a weak peak at $634 \mathrm{~cm}^{-1}$ was detected, ascribed to the $\mathrm{Fe}-\mathrm{O}$ vibration of $\mathrm{Fe}_{3} \mathrm{O}_{4}$ [44].

The $\mathrm{N}_{2}$ adsorption/desorption isotherms of the $\mathrm{Fe}_{3} \mathrm{O}_{4} @ N C s$ display a mixture of type I and IV shape, demonstrating coexistence of micropores and mesopores (Fig. S5). The corresponding pore-size distribution curves of $\mathrm{Fe}_{3} \mathrm{O}_{4} @ \mathrm{NCs}$ are displayed in the insets of Fig. S5. The specific surface areas calculated by Brunauer-EmmettTeller (BET) method are 181, 305 and $137 \mathrm{~m}^{2} \mathrm{~g}^{-1}$ for $\mathrm{Fe}_{3} \mathrm{O}_{4} @ \mathrm{NC}-600, \mathrm{Fe}_{3} \mathrm{O}_{4} @ \mathrm{NC}-700$ and $\mathrm{Fe}_{3} \mathrm{O}_{4} @ \mathrm{NC}-800$, respectively. By comparison, $\mathrm{Fe}_{3} \mathrm{O}_{4} @ \mathrm{NC}-700$ has the largest specific surface area with abundant microspores centered at $0.5 \mathrm{~nm}$, leading to more active sites exposed and ion diffusion path shortened.

XPS analysis was performed to further clarify the chemical composition and environment of the obtained samples. As shown in Fig. S6, the survey spectra indicate the presence of $\mathrm{C}, \mathrm{N}, \mathrm{O}$ and $\mathrm{Fe}$ elements in the $\mathrm{Fe}_{3} \mathrm{O}_{4} @$ NC composites. PANI precursor can provide a high degree of nitrogen doping and the $\mathrm{N}$ contents are $10.8 \%$, 8.0\% and 5.0\% in $\mathrm{Fe}_{3} \mathrm{O}_{4} @ \mathrm{NC}-600, \mathrm{Fe}_{3} \mathrm{O}_{4} @ \mathrm{NC}-700$ and $\mathrm{Fe}_{3} \mathrm{O}_{4} @ \mathrm{NC}-800$, respectively. Fe 2p XPS spectra (Fig. 1i) exhibit two major peaks at 710.9 and $724.9 \mathrm{eV}$, corresponding to $\mathrm{Fe} 2 \mathrm{p}_{3 / 2}$ and $\mathrm{Fe} 2 \mathrm{p}_{1 / 2}$ spin-orbit peaks, respectively. It further indicates the formation of $\mathrm{Fe}_{3} \mathrm{O}_{4}$ [45]. The deconvoluted peaks of C 1s (Fig. S7) at 284.6, $285.8,286.7$, and $288.6 \mathrm{eV}$ can be ascribed to $\mathrm{C}=\mathrm{C}, \mathrm{C}-\mathrm{N}$, $\mathrm{C}-\mathrm{O}-\mathrm{C}$, and $\mathrm{C}-\mathrm{O}$, respectively [26]. The characteristic peak of $\mathrm{C}-\mathrm{N}$ demonstrates the presence of $\mathrm{N}$-doping. As shown in Fig. 1j, the high-resolution N 1s XPS spectrum could be deconvoluted into four peaks centered at 398.2, $400.2,401.2$ and $403.8 \mathrm{eV}$, attributed to the pyridinic- $\mathrm{N}$, pyrrolic- $\mathrm{N}$, quaternary- $\mathrm{N}$ and pyridine- $\mathrm{N}$-oxide group, respectively [46]. As listed in Table S1, the content of quaternary- $\mathrm{N}$ is significantly increased while the contents of pyridinic- $\mathrm{N}$ and pyrrolic- $\mathrm{N}$ are decreased as the pyrolysis temperature increases from 600 to $800^{\circ} \mathrm{C}$, indicating better thermal stability of quaternary- $\mathrm{N}$ [47]. Pyridinic- $\mathrm{N}$ is referred to any $\mathrm{N}$ with one p-electron on $\pi$ system, and pyrrolic- $\mathrm{N}$ is referred to any $\mathrm{N}$ with two $\mathrm{p}$ electrons on $\pi$ system [48]. These $\mathrm{N}$-containing func- tionalities could increase the electronic density of the carbon network, favor ion adsorption, and improve carbon wettability. Quaternary-N can effectively improve the electronic conductivity of the materials but is generally less active than other nitrogen functionalities [49]. These XPS results clearly demonstrate the formation of $\mathrm{Fe}_{3} \mathrm{O}_{4}$ and highly $\mathrm{N}$-doped carbon in the $\mathrm{Fe}_{3} \mathrm{O}_{4} @ \mathrm{NC}$ composites.

Fig. 2 shows the electrochemical performances of the $\mathrm{Fe}_{3} \mathrm{O}_{4} @ \mathrm{NC}$ electrode by half-cell tests. First, CV measurement was carried out at a scan rate of $0.1 \mathrm{mV} \mathrm{s}^{-1}$ in the potential range of $0.01-3 \mathrm{~V}$ to investigate the electrochemical behaviors. As shown in Fig. 2a, the first cycle of the $\mathrm{Fe}_{3} \mathrm{O}_{4} @ \mathrm{NC}-700$ electrode exhibits two cathodic peaks at about 1.60 and $0.57 \mathrm{~V}$, respectively. The weak peak around $1.60 \mathrm{~V}$ is usually ascribed to the initial lithium insertion into $\mathrm{Fe}_{3} \mathrm{O}_{4}$ to form $\mathrm{Li}_{2} \mathrm{Fe}_{3} \mathrm{O}_{4}[50,51]$. The sharp peak around $0.57 \mathrm{~V}$ is attributed to the irreversible formation of SEI layer, as well as the reduction of $\mathrm{Fe}^{3+}$ and $\mathrm{Fe}^{2+}$ to $\mathrm{Fe}^{0}$. At the anodic scan, two peaks at 1.67 and $1.91 \mathrm{~V}$ are assigned to the reversible oxidation of $\mathrm{Fe}^{0}$ to $\mathrm{Fe}^{2+}$ and $\mathrm{Fe}^{3+}$, respectively. The multiple cathodic peaks at 0.93 and $1.39 \mathrm{~V}$ and anodic peaks at 1.67 and $1.91 \mathrm{~V}$ are in the following cycles. Moreover, the CV curves after the first cycle are well overlapped, suggesting that a stable SEI layer was formed on the carbon shells. The SEI layer can not only prevent the direct contact of the interior $\mathrm{Fe}_{3} \mathrm{O}_{4}$ nanoparticles with the electrolyte but also maintain the structural integrity of the $\mathrm{Fe}_{3} \mathrm{O}_{4}$ nanoparticles [50]. The total electrochemical reactions involved in the cycles are expressed in the following equations [52]:

$$
\begin{aligned}
& \mathrm{Fe}_{3} \mathrm{O}_{4}+2 \mathrm{Li}^{+}+2 \mathrm{e}^{-} \rightarrow \mathrm{Li}_{2} \mathrm{Fe}_{3} \mathrm{O}_{4}, \\
& \mathrm{Li}_{2} \mathrm{Fe}_{3} \mathrm{O}_{4}+6 \mathrm{Li}^{+}+6 \mathrm{e}^{-} \rightarrow 3 \mathrm{Fe}^{0}+4 \mathrm{Li}_{2} \mathrm{O}, \\
& 3 \mathrm{Fe}^{0}+4 \mathrm{Li}_{2} \mathrm{O} \rightarrow \mathrm{Fe}_{3} \mathrm{O}_{4}+8 \mathrm{Li}^{+}+8 \mathrm{e}^{-} .
\end{aligned}
$$

The GCD curves were obtained at a current density of $100 \mathrm{~mA} \mathrm{~g}^{-1}$ (Fig. 2b). The $\mathrm{Fe}_{3} \mathrm{O}_{4} @ \mathrm{NC}-700$ electrode exhibits an obvious lithium insertion plateau in the first discharge cycle and an irreversible capacity loss of $47.2 \%$, primarily caused by the inevitable formation of SEI layer and the decomposition of the electrolyte. Note that the subsequent GCD cycles show a dominated linear slope discharge curve without obvious lithium insertion plateau while a plateau is expected for a bulk material undergoing a phase transformation during the redox reaction [53]. It implys that the nanostructured $\mathrm{Fe}_{3} \mathrm{O}_{4} @ \mathrm{NC}-700$ exhibits pseudocapacitive behavior. Some nanoscaled battery-type transition metal oxides have been proved exhibiting significant pseudocapacitance [54-56]. It is explained that 

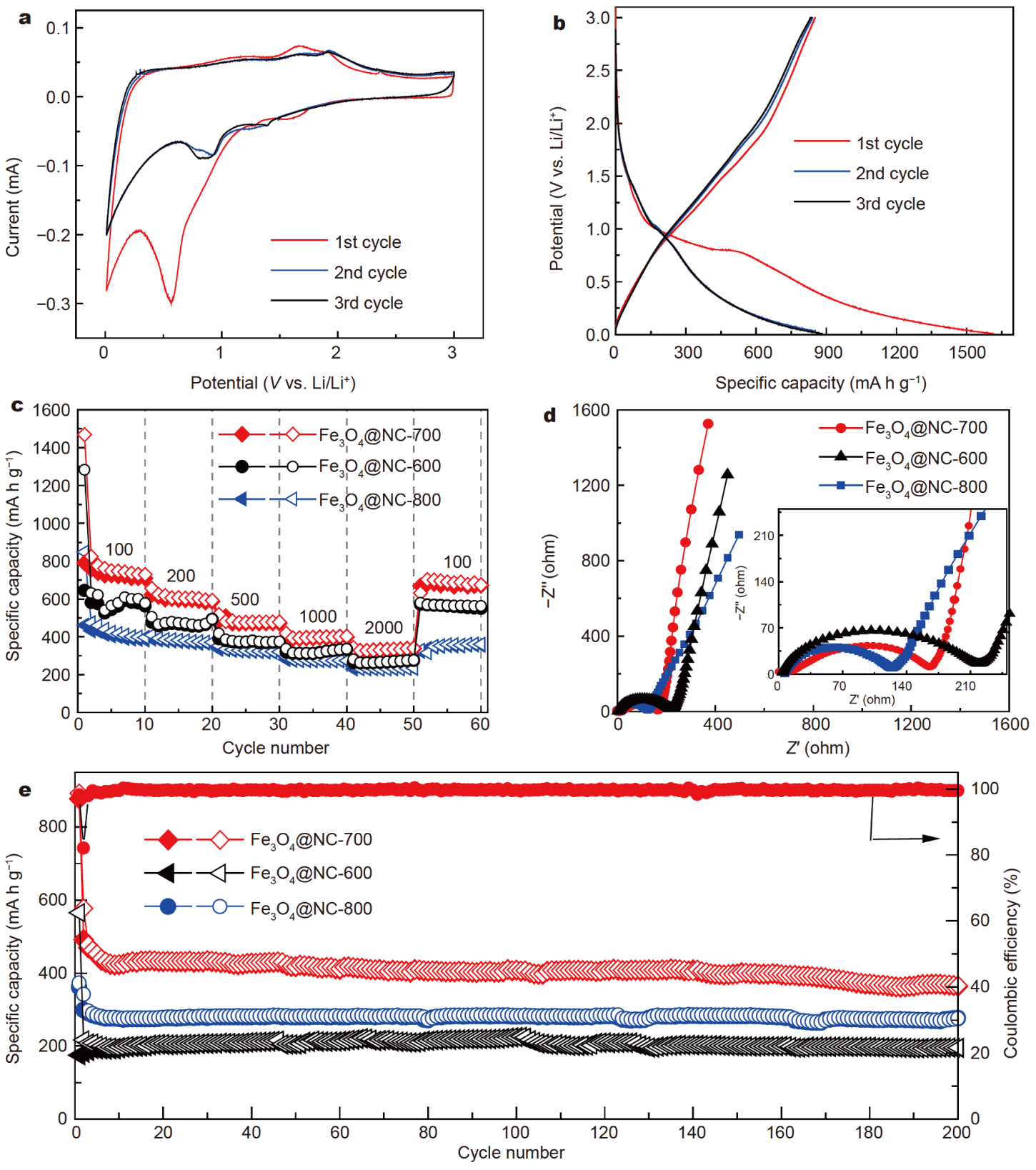

Figure 2 (a) CV curves of the $\mathrm{Fe}_{3} \mathrm{O}_{4} @ \mathrm{NC}-700$ electrode in the first three charge-discharge cycles at a scan rate of $0.1 \mathrm{mV} \mathrm{s}^{-1}$. (b) GCD curves of the $\mathrm{Fe}_{3} \mathrm{O}_{4} @ \mathrm{NC}-700$ in the first three cycles at a current density of $100 \mathrm{~mA} \mathrm{~g}$. (c) Rate performance at different current densities (the numbers are different current densities, $\mathrm{mA} \mathrm{g}^{-1}$ ). (d) Nyquist plots in a frequency range of $0.01 \mathrm{~Hz}$ to $100 \mathrm{kHz}$ and (e) long-term cycling stability of Fe $\mathrm{O}_{4} @ \mathrm{NC}$ $600, \mathrm{Fe}_{3} \mathrm{O}_{4} @ \mathrm{NC}-700$ and $\mathrm{Fe}_{3} \mathrm{O}_{4} @ \mathrm{NC}-800$ at a current density of $500 \mathrm{~mA} \mathrm{~g}^{-1}$.

the increase of surface area through nanostructuring leads to a decrease in diffusion path, the suppression of a phase transformation and increased surface lithium ion storage sites [7]. The pseudocapacitive behavior of these nanoscaled materials is expected to overcome kinetic limitation of slow solid-state diffusivity of $\mathrm{Li}^{+}$ions in transition metal oxides, leading to improved high-rate performance [9].
$\mathrm{Fe}_{3} \mathrm{O}_{4} @ \mathrm{NC}-600, \mathrm{Fe}_{3} \mathrm{O}_{4} @ \mathrm{NC}-700$ and $\mathrm{Fe}_{3} \mathrm{O}_{4} @ \mathrm{NC}-800$ were compared to investigate the impact of pyrolysis tempeature on the electrochemical performance. As shown in Fig. 2c, $\mathrm{Fe}_{3} \mathrm{O}_{4} @ \mathrm{NC}-700$ delivers the highest specific capacity of $730 \mathrm{~mA} \mathrm{~h} \mathrm{~g}^{-1}$ at $100 \mathrm{~mA} \mathrm{~g}^{-1}$ and that of $344 \mathrm{~mA} \mathrm{~h} \mathrm{~g}^{-1}$ at a high current density of $2000 \mathrm{~mA} \mathrm{~g}^{-1}$. More importantly, after undergoing different ultrahigh rate cycles, nearly $100 \%$ of the capacity can be restored 
when the current density switches back to $100 \mathrm{~mA} \mathrm{~g}^{-1}$, demonstrating a good electrochemical stability. What's more, we also performed the EIS measurements of the three electrodes, respectively. Fig. $2 \mathrm{~d}$ shows the corresponding Nyquist plots in a frequency range of $0.01 \mathrm{~Hz}$ to $100 \mathrm{kHz}$. The depressed semicircle appearing in the medium frequency range is related with the charge transfer resistance $R_{\mathrm{ct}}$ between the active materials and liquid electrolyte, while the inclined line in the low frequency region is associated with the Warburg impedance $R_{\mathrm{w}}$ reflecting the solid-state diffusion of Li ions in the active materials. It can be found that the $R_{\mathrm{ct}}$ values of $\mathrm{Fe}_{3} \mathrm{O}_{4} @ \mathrm{NC}-600, \mathrm{Fe}_{3} \mathrm{O}_{4} @ \mathrm{NC}-700$ and $\mathrm{Fe}_{3} \mathrm{O}_{4} @ \mathrm{NC}-800$ are 219.3, 165.2 and $122.4 \Omega$, demonstrating the good electronic conductivity of $\mathrm{Fe}_{3} \mathrm{O}_{4} @ \mathrm{NC}-700$ and that the electronic conductivity is enhanced by increasing the pyrolysis temperatures. In addition, the more-vertical line of $\mathrm{Fe}_{3} \mathrm{O}_{4} @ \mathrm{NC}-700$ in the low frequency region suggests its improved $\mathrm{Li}^{+}$diffusion process and strengthened capacitive-like behavior [35].

The cycle performance of the $\mathrm{Fe}_{3} \mathrm{O}_{4} @ \mathrm{NC}$ electrodes is depicted in Fig. 2e. Strikingly, all three electrodes exhibit good cycling stability. After 200 charge-discharge cycles at a relatively high current density of $500 \mathrm{~mA} \mathrm{~g}^{-1}$, no obvious degradation appears for the three electrodes and the specific capacities are 195, 365 and $278 \mathrm{~mA} \mathrm{~h} \mathrm{~g}^{-1}$ for $\mathrm{Fe}_{3} \mathrm{O}_{4} @ \mathrm{NC}-600, \mathrm{Fe}_{3} \mathrm{O}_{4} @ \mathrm{NC}-700$ and $\mathrm{Fe}_{3} \mathrm{O}_{4} @ \mathrm{NC}-800$, respectively. The corresponding Coulombic efficiency of $\mathrm{Fe}_{3} \mathrm{O}_{4} @ \mathrm{NC}-700$ is nearly $100 \%$. Besides, the cycle performance of $\mathrm{Fe}_{3} \mathrm{O}_{4} @ \mathrm{NC}-700$ was also measured at a high current density of $1000 \mathrm{~mA} \mathrm{~g}^{-1}$ for 1000 cycles. As shown in Fig. S8, after the initial capacity loss during the first few cycles, $\mathrm{Fe}_{3} \mathrm{O}_{4} @ \mathrm{NC}-700$ shows a slight capacity increase in the following cycles due to the activation process. After cycling for 1000 times, $\mathrm{Fe}_{3} \mathrm{O}_{4} @ \mathrm{NC}-700$ still delivers a high discharge capacity of $371 \mathrm{~mA} \mathrm{~h} \mathrm{~g}^{-1}$, showing a high-capacity retention with a Coulombic effciency of nearly $100 \%$. It demonstrates that the coating of $\mathrm{Fe}_{3} \mathrm{O}_{4}$ with $\mathrm{N}$ rich carbon helps to maintain the electrical continuity and structural integrity during cycling at high rates. The structural stability can be confirmed by the SEM image of $\mathrm{Fe}_{3} \mathrm{O}_{4} @ \mathrm{NC}-700$ after 1000 discharge/charge cycles at $1000 \mathrm{~mA} \mathrm{~g}^{-1}$. As shown in Fig. S9, $\mathrm{Fe}_{3} \mathrm{O}_{4} @ \mathrm{NC}-700$ still presents a rather homogeneous spherical morphology without obvious structure failure and pulverization after 1000 cycles at $1000 \mathrm{~mA} \mathrm{~g}^{-1}$.

Overall, $\mathrm{Fe}_{3} \mathrm{O}_{4} @ \mathrm{NC}-700$ has been endowed with the most fascinating electrochemical performance among the three $\mathrm{Fe}_{3} \mathrm{O}_{4} @ \mathrm{NC}$ electrodes and the main reasons are as follows: on the one hand, $\mathrm{Fe}_{3} \mathrm{O}_{4} @ \mathrm{NC}-700$ has the highest
BET specific surface area with abundant micropores, leading to more active sites exposed and ion diffusion path shortened. On the other hand, the appropriate ratio of pyridinic- $\mathrm{N}$ and pyrrolic- $\mathrm{N}$ to quaternary- $\mathrm{N}$ ensures both abundant active sites and good electronic conductivity.

To further investigate the electrochemical properties of the $\mathrm{Fe}_{3} \mathrm{O}_{4} @ \mathrm{NC}-700$ electrode, CV curves at different scan rates from 0.2 to $1.0 \mathrm{mV} \mathrm{s}^{-1}$ were measured to evaluate the quantitative capacity (Fig. 3a). The relationship between the peak current $(i)$ and scan rate $(v)$ can be expressed as Equation (9) [57]:

$\ln i=\ln a+b \ln v$,

where $a$ and $b$ are two adjustable parameters. According to previous research, the $b$-value is equal to the slope of the fitted line (herein, 0.5 notes diffusion-controlled contribution and 1.0 suggests capacitive-effect contribution) [58]. In the current study, the $b$-values of $\mathrm{Fe}_{3} \mathrm{O}_{4} @$ NC-700 for two anodic peaks and two cathodic peaks are calculated to be $0.85,0.87,0.81$ and 0.94 , respectively (Fig. 3b). This implys that the electrochemical kinetics of $\mathrm{Fe}_{3} \mathrm{O}_{4} @ \mathrm{NC}-700$ electrode is a dominant capacitive-effectcontrolled pseudocapacitive behavior.

In order to distinguish the capacitive contribution to the current response of CV curves, Equation (9) can be converted to Equation $(10)[59,60]$ :

$i(v)=k_{1} v+k_{2} v^{1 / 2}$,

where $k_{1}$ represents the capacitive effect and $k_{2}$ represents the diffusion-controlled contribution. Typically, Fig. 3c shows the $\mathrm{CV}$ curve with capacitive contribution at a scan rate of $0.5 \mathrm{mV} \mathrm{s}^{-1}$. The shade and blank areas are presented as the capacitive-effect and diffusion-controlled capacities, respectively. As shown in Fig. 3d, the contribution of the capacitive capacity to the total capacity at different scan rates are $39.8 \%, 42.4 \%, 51.3 \%, 61.6 \%$ and $69.7 \%$, respectively. It is obvious that the percentage of capacitive contribution gradually increases with the increasing scan rates from 0.2 to $1.0 \mathrm{mV} \mathrm{s}^{-1}$. This result confirms that the surface capacitive effect plays a dominant role in the rapid charge-discharge process in $\mathrm{Fe}_{3} \mathrm{O}_{4} @ \mathrm{NC}-700$. Benefiting from a dominant capacitiveeffect-controlled pseudocapacitive behavior, $\mathrm{Fe}_{3} \mathrm{O}_{4} @ \mathrm{NC}$ 700 has the effectively improved rate capability, which establishes its feasibility as an negative electrode material in LICs.

\section{Characterizations of the EGN positive electrode}

Before fabrication of the LIC device, the positive electrode material EGN was synthesized and characterized. The 

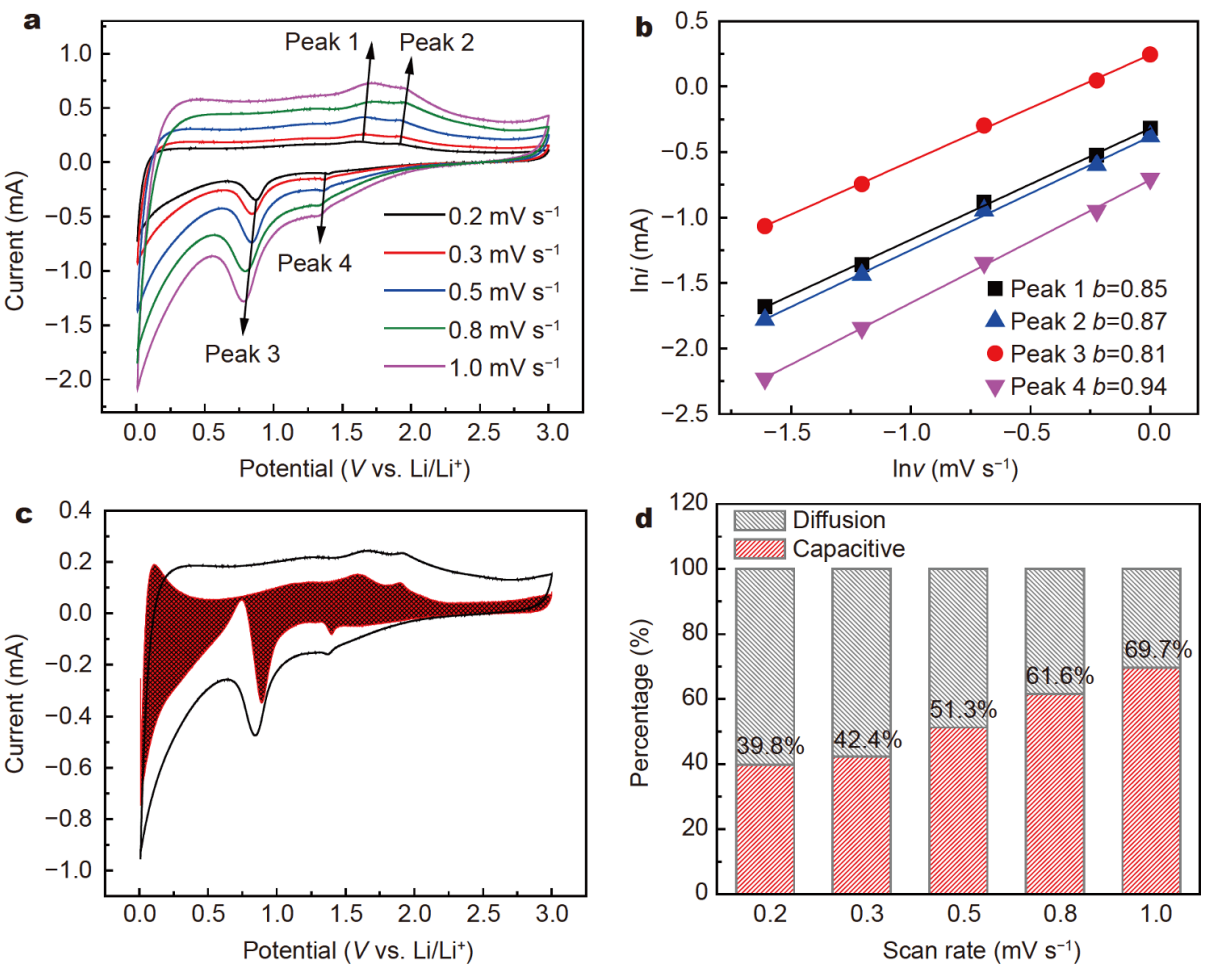

Figure 3 Electrochemical properties of the $\mathrm{Fe}_{3} \mathrm{O}_{4} @ \mathrm{NC}-700$ electrode. (a) CV curves at various scan rates. (b) Correlations of charging/discharging peak current density $(i)$ and scan rate $(v)$. (c) CV response at a scan rate of $0.5 \mathrm{mV} \mathrm{s}^{-1}$ and the part of capacitive contribution is marked by shadow region. (d) The percentages of capacitive contribution at different scan rates.

microstructure of the as-prepared EGN was observed from SEM and TEM images. As shown in Fig. 4a and Fig. S10a, the obtained EGN exhibits an accordion-like layer-by-layer structure composed of ultrathin nanosheets with curled and wavy wrinkles. The crystal structure was investigated by XRD as given in Fig. S10b. The EGN shows two broad peaks at around $24.1^{\circ}$ and $43.4^{\circ}$ originating from (002) and (100) crystal planes of partiallygraphitized porous carbon layer [61], without other impurity peaks. The $\mathrm{N}_{2}$ adsorption/desorption isotherms and the corresponding pore-size distribution curve of the EGN were measured (Fig. 4b). The $\mathrm{N}_{2}$ adsorption/desorption isotherms are typical type-IV with a hysteresis loop in a relative pressure range of $0.4-0.95$, indicating the mesoporous feature. The BET specific surface area is $191.1 \mathrm{~m}^{2} \mathrm{~g}^{-1}$. The interconnected multimodal pore-size distribution clearly reveals that micropores $(<2 \mathrm{~nm})$, mesopores $(2-50 \mathrm{~nm})$ and macropores $(>50 \mathrm{~nm})$ co-exist simultaneously in the EGN. Such a hierarchically porous structure with a high specific surface area is favorable for accelerating ion diffusion and improving energy storage.

FT-IR was used to analyze the chemical bonds and functional groups. As shown in Fig. S10c, the peaks of
GO around 1730, 1627, 1407, 1232 and $1053 \mathrm{~cm}^{-1}$ are assigned to the characteristic vibrations of $\mathrm{C}-\mathrm{O}$ in $\mathrm{COOH}$, intercalated water, $\mathrm{O}=\mathrm{C}-\mathrm{O}$ from carboxylate, epoxy $\mathrm{C}-\mathrm{O}$ and $\mathrm{C}-\mathrm{O}$ in $\mathrm{C}-\mathrm{OH} / \mathrm{C}-\mathrm{O}-\mathrm{C}$ functional groups, respectively [62]. These absorption peaks of oxygen-containing groups are dramatically weaker in the EGN, suggesting that most of the oxygen-containing groups have been removed at high temperature. The composition and chemical states were analyzed with XPS. The survey spectra (Fig. S10d) reveal that the $\mathrm{C} / \mathrm{O}$ atomic ratio in the EGN is obviously much higher than that in GO. As shown in Fig. 4c, the $\mathrm{C}$ 1s spectra of the EGN and $\mathrm{GO}$ can both be fitted with four peaks, that is, $\mathrm{C}-\mathrm{C} / \mathrm{C}=\mathrm{C}$, $\mathrm{C}-\mathrm{O}, \mathrm{C}=\mathrm{O}$ and $\mathrm{O}=\mathrm{C}-\mathrm{O}$. Compared with $\mathrm{GO}$, the contents of oxygen-related groups are apparently decreased in the EGN [63]. It further confirms the reduction of oxygen-related groups of GO.

The capacitive performance of the EGN was evaluated by CV and GCD tests in a half-cell system. The potential range was set between 2.5 and $4.5 \mathrm{~V}\left(v s . \mathrm{Li} / \mathrm{Li}^{+}\right)$that would provide a large potential window for the assembled LICs. Fig. $4 \mathrm{~d}$ shows the CV curves of EGN at various scan rates from 2.0 to $50 \mathrm{mV} \mathrm{s}^{-1}$. All $\mathrm{CV}$ curves exhibit a 

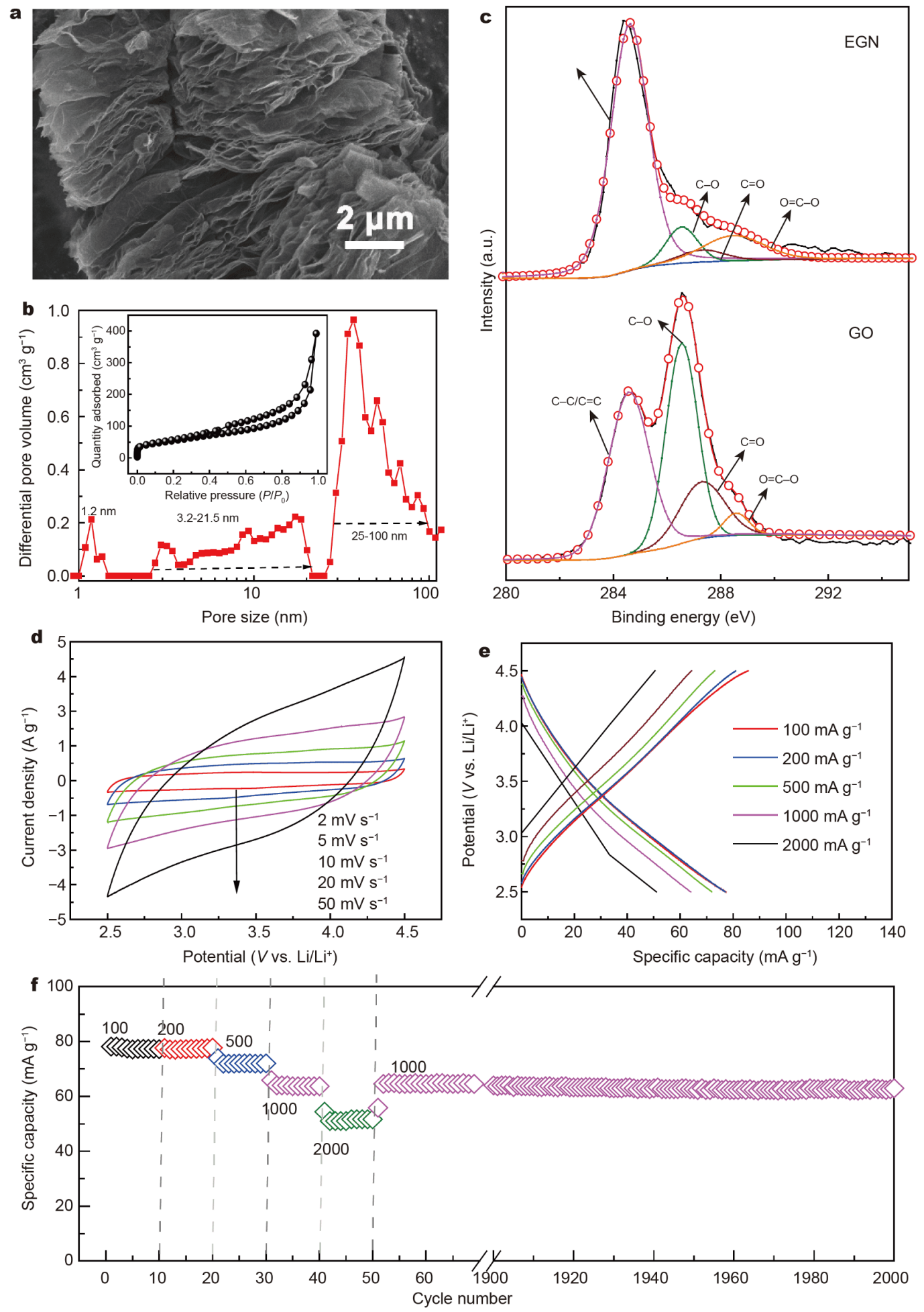

Figure 4 Morphological and structural characterizations of the EGN (a-c). (a) SEM image, (b) pore-size distribution curve (inset is the $\mathrm{N}_{2}$ adsorption/desorption isotherm) and (c) high-resolution C 1s XPS spectra of GO and EGN. Electrochemical performance of the EGN electrode (d-f). (d) CV curves at different scan rates from 2 to $50 \mathrm{mV} \mathrm{s}^{-1}$, (e) GCD curves at different current densities from 100 to $2000 \mathrm{~mA} \mathrm{~g}^{-1}$ and (f) rate performance at different current densities (left) and cycle stability at a current density of $1000 \mathrm{~mA} \mathrm{~g}^{-1}$ (right). 
quasi-rectangular shape, suggesting the dominant ideal electric double layer capacitance. Fig. 4e shows the GCD curves of the EGN electrode at different current densities. The linear and symmetric nature of these GCD profiles further confirms the capacitive behavior of this electrode material through adsorption/desorption of anions. Impressively, the EGN exhibits a relatively high specific capacity of $78.1 \mathrm{~mA} \mathrm{~h} \mathrm{~g}^{-1}$ at $100 \mathrm{~mA} \mathrm{~g}^{-1}$, much higher than that of commercial $\mathrm{AC}\left(35 \mathrm{~mA} \mathrm{~h} \mathrm{~g}^{-1}\right)$ and other carbon-based positive electrodes $[26,64]$.

To further evaluate the rate performance and long-term cycling stability, the EGN was examined at different current densities from 100 to $2000 \mathrm{~mA} \mathrm{~g}^{-1}$ and cycled at $1000 \mathrm{~mA} \mathrm{~g}^{-1}$ for 2000 charge-discharge tests. As shown in Fig. 4f, the specific capacity of the EGN can still reach $51.6 \mathrm{~mA} \mathrm{~h} \mathrm{~g}^{-1}$ at a high current density of $2000 \mathrm{~mA} \mathrm{~g}^{-1}$, demonstrating an excellent rate capability, which could be ascribed to the low $R_{\mathrm{ct}}$, appropriate surface functional groups, and suitable pore-size distribution [65]. After 2000 cycles at a current density of $1000 \mathrm{~mA} \mathrm{~g}^{-1}$, the EGN presents no obvious fade of initial capacity, indicating a superior cycling stability. These results strongly demonstrate the encouraging advantages of the EGN in terms of its large specific capacity, superior rate capability and good electrochemical stability, showing great potential as a positive material for LICs.

\section{LIC based on $\mathrm{Fe}_{3} \mathrm{O}_{4} @ \mathrm{NC}-700$ and EGN}

We designed an LIC in $\mathrm{LiPF}_{6}$-containing organic electrolyte, consisting of the $\mathrm{Fe}_{3} \mathrm{O}_{4} @ \mathrm{NC}-700$ negative electrode and EGN positive electrode. As shown in Fig. 5a, during the charge process, $\mathrm{PF}_{6}{ }^{-}$ions are rapidly adsorbed at the surface and interlayers of the EGN nanosheets, while $\mathrm{Li}^{+}$ions from electrolyte are intercalated into $\mathrm{Fe}_{3}$ $\mathrm{O}_{4} @ \mathrm{NC}-700$. During the discharge, $\mathrm{PF}_{6}{ }^{-}$ions leave EGN meanwhile $\mathrm{Li}^{+}$ions depart from $\mathrm{Fe}_{3} \mathrm{O}_{4} @ \mathrm{NC}-700$. The electrochemical performance of the $\mathrm{Fe}_{3} \mathrm{O}_{4} @ \mathrm{NC}-700 / /$ EGN LIC was measured in the potential range of $1.0-4.5 \mathrm{~V}$ to avoid electrolyte oxidation at the positive electrode and lithium plating at the negative electrode. The CV curves at different scan rates all show a quasirectangular shape (Fig. 5b), suggesting that the kinetics of the two electrodes are well matched and balanced. Moreover, the GCD profiles at different current densities exhibit a quasi-symmetric triangular shape (Fig. 5c), further confirming that the pseudo-capacitance of $\mathrm{Fe}_{3}$ $\mathrm{O}_{4} @ \mathrm{NC}-700$ and the electric double layer capacitance of EGN are well integrated in the device. As shown in Fig. 5d, the $\mathrm{Fe}_{3} \mathrm{O}_{4} @ \mathrm{NC}-700 / / \mathrm{EGN}$ LIC has the highest capacitance of $\sim 51.8 \mathrm{~F} \mathrm{~g}^{-1}$ at a current density of
$100 \mathrm{~mA} \mathrm{~g}^{-1}$ and a capacitance of $15.0 \mathrm{~F} \mathrm{~g}^{-1}$ at a very high current density of $3000 \mathrm{~mA} \mathrm{~g}^{-1}$.

In order to further evaluate the practical applicability of the LIC system, Ragone plot (energy density $v s$. power density) of the $\mathrm{Fe}_{3} \mathrm{O}_{4} @ \mathrm{NC}-700 / / \mathrm{EGN}$ LIC is shown in Fig. 5e along with other reported LICs. The energy and power densities were calculated based on the total mass of the two electrodes. At a low power density of $275 \mathrm{~W} \mathrm{~kg}^{-1}$, the LIC can achieve an ultrahigh energy density of $137.5 \mathrm{~W} \mathrm{~h} \mathrm{~kg}^{-1}$. When the power density increases to $8250 \mathrm{~W} \mathrm{~kg}^{-1}$, the energy density can still deliver a value of $39 \mathrm{~W} \mathrm{~h} \mathrm{~kg}^{-1}$, suggesting the favorable properties from the collaborative advantages of LIBs and SCs. The remarkable energy and power densities of the $\mathrm{Fe}_{3} \mathrm{O}_{4} @ \mathrm{NC}-700 / / \mathrm{EGN}$ LIC are superior to those of other previously reported

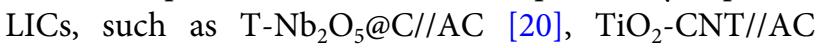
[66], $\mathrm{Li}_{4} \mathrm{Ti}_{5} \mathrm{O}_{12} / /$ reduced GO [24], $\mathrm{Ti}_{2} \mathrm{C}$ MXene//AC [67], $\mathrm{Fe}_{x} \mathrm{O} @$ graphene//porous [68], etc. (see Table S2). In addition, the $\mathrm{Fe}_{3} \mathrm{O}_{4} @ \mathrm{NC}-700 / / \mathrm{EGN}$ LIC also exhibits an excellent cycling stability. As shown in Fig. 5f, although the $\mathrm{Fe}_{3} \mathrm{O}_{4} @$ NC-700//EGN LIC somehow displays a dramatically capacity decrease of $\sim 35.1 \%$ during the first 5000 cycles, it still keeps a rather stable capacity retention of $63.4 \%$ for the following 15,000 cycles at a high current density of $1000 \mathrm{~mA} \mathrm{~g}^{-1}$.

The remarkable electrochemical performance of the $\mathrm{Fe}_{3} \mathrm{O}_{4} @ \mathrm{NC}-700 / /$ EGN LIC can be mainly attributed to the following aspects: (1) the nanostructured subunits and abundant micropores endow $\mathrm{Fe}_{3} \mathrm{O}_{4} @ \mathrm{NC}-700$ with a high specific area, more active sites exposed, and ion diffusion path shortened, being favorable for a highly/ special pseudocapacitive behavior and significantly improved $\mathrm{Li}^{+}$-storage kinetics. In addition, the coating of $\mathrm{Fe}_{3} \mathrm{O}_{4}$ nanoparticles with $\mathrm{N}$-rich carbon ensures the electrical continuity and structural integrity during cycling. (2) The hierarchically porous framework of EGN with a large specific surface area and a high eletronic conductivity gives rise to the fast charge transfer and high specific capacity. (3) The well-matched $\mathrm{Fe}_{3} \mathrm{O}_{4} @ \mathrm{NC}-700$ negative electrode and EGN positive electrode effectively alleviate the kinetics imbalance between the two electrodes, leading to high energy and power densities of the assembled LIC as well as a good cycling stability.

\section{CONCLUSIONS}

In summary, we prepared the $\mathrm{Fe}_{3} \mathrm{O}_{4}$ nanoparticles encapsulated in nitrogen-rich carbon and investigated the influence of pyrolysis temperature on the electrochemical performances. It was found that $\mathrm{Fe}_{3} \mathrm{O}_{4} @ \mathrm{NC}-700$ could deliver a high capacity with a good rate capability and a 

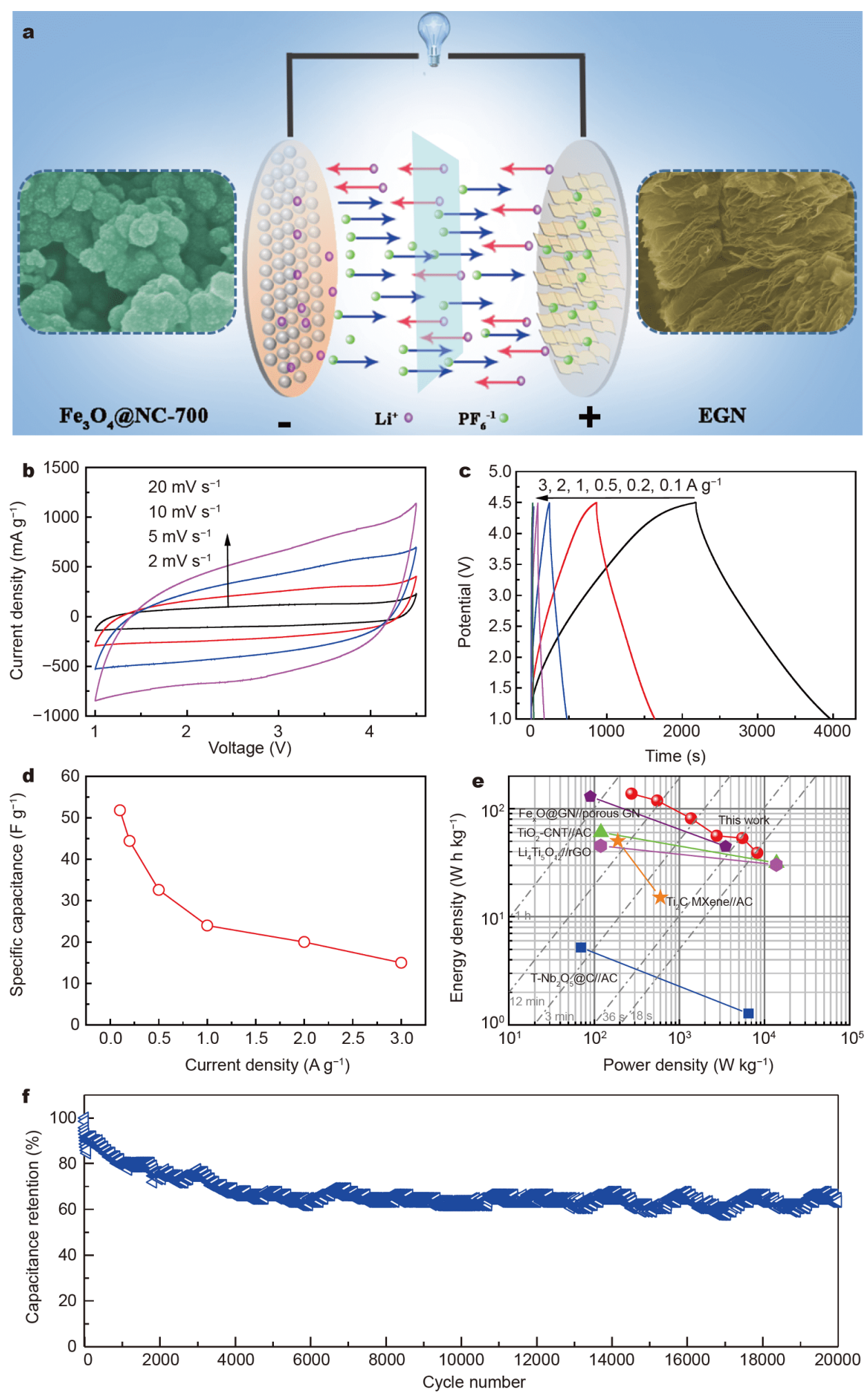

Figure 5 Electrochemical performances of the $\mathrm{Fe}_{3} \mathrm{O}_{4} @ N C-700 / / E G N$ LIC. (a) Schematic illustration of the design and charge-storage mechanism of the $\mathrm{Fe}_{3} \mathrm{O}_{4} @ \mathrm{NC}-700$ negative electrode and EGN positive electrode in the present LIC system. (b) CV curves between 1.0 and $4.5 \mathrm{~V}$ at various scan rates. (c) GCD curves at different current densities. (d) Specific capacitance at different current densities. (e) Ragone plots of the Fe $\mathrm{O}_{4} @ \mathrm{NC}-700 / /$ EGN and other related LICs. (f) Cycling performance at a current density of $1000 \mathrm{~mA} \mathrm{~g}^{-1}$. 
long cycling stability due to the nanostructured subunits, conductive nitrogen-rich carbon shells, abundant micropores and high specific surface area. A detailed electrochemical kinetic analysis reveals that $\mathrm{Fe}_{3} \mathrm{O}_{4} @ \mathrm{NC}-700$ has a dominant capacitive-effect-controlled pseudocapacitive behavior. An LIC has been successfully designed with $\mathrm{Fe}_{3} \mathrm{O}_{4} @ \mathrm{NC}-700$ as the negative electrode and EGN as the positive electrode. Due to the well-matched kinetics between the two electrodes and the collaborative advantages of $\mathrm{Fe}_{3} \mathrm{O}_{4} @ \mathrm{NC}-700$ and EGN, the as-fabricated LIC exhibits a large working voltage window $(1.0-4.5 \mathrm{~V})$, a high energy density (up to $137 \mathrm{~W} \mathrm{~h} \mathrm{~kg}^{-1}$ ) and a high power density (up to $8.2 \mathrm{~kW} \mathrm{~kg}^{-1}$ ) as well as a long cycle life. This study may provide a new inspiration for the design of next generation hybrid electrochemical energy storage systems with both high energy and power densities.

\section{Received 21 January 2020; accepted 31 May 2020;} published online 30 July 2020

1 Simon P, Gogotsi Y, Dunn B. Where do batteries end and supercapacitors begin? Science, 2014, 343: 1210-1211

2 Winter M, Brodd RJ. What are batteries, fuel cells, and supercapacitors? Chem Rev, 2005, 104: 4245-4270

3 Chen $\mathrm{H}$, Cong TN, Yang W, et al. Progress in electrical energy storage system: A critical review. Prog Nat Sci, 2009, 19: 291-312

4 Kim H, Cho MY, Kim MH, et al. A novel high-energy hybrid supercapacitor with an anatase $\mathrm{TiO}_{2}$-reduced graphene oxide anode and an activated carbon cathode. Adv Energy Mater, 2013, 3: 1500-1506

5 Shan XY, Wang Y, Wang DW, et al. Armoring graphene cathodes for high-rate and long-life lithium ion supercapacitors. Adv Energy Mater, 2016, 6: 1502064

6 Zhang F, Zhang T, Yang X, et al. A high-performance supercapacitor-battery hybrid energy storage device based on grapheneenhanced electrode materials with ultrahigh energy density. Energy Environ Sci, 2013, 6: 1623-1632

7 Augustyn V, Simon P, Dunn B. Pseudocapacitive oxide materials for high-rate electrochemical energy storage. Energy Environ Sci, 2014, 7: 1597-1614

8 Dubal DP, Ayyad O, Ruiz V, et al. Hybrid energy storage: the merging of battery and supercapacitor chemistries. Chem Soc Rev, 2015, 44: 1777-1790

9 Ding J, Hu W, Paek E, et al. Review of hybrid ion capacitors: from aqueous to lithium to sodium. Chem Rev, 2018, 118: 6457-6498

10 Kim JH, Kim JS, Lim YG, et al. Effect of carbon types on the electrochemical properties of negative electrodes for Li-ion capacitors. J Power Sources, 2011, 196: 10490-10495

11 Wang $\mathrm{H}$, Zhu C, Chao D, et al. Nonaqueous hybrid lithium-ion and sodium-ion capacitors. Adv Mater, 2017, 29: 1702093

12 Amatucci GG, Badway F, Du Pasquier A, et al. An asymmetric hybrid nonaqueous energy storage cell. J Electrochem Soc, 2001, 148: A930

13 Pasquier AD, Plitz I, Gural J, et al. Characteristics and performance of $500 \mathrm{~F}$ asymmetric hybrid advanced supercapacitor prototypes. J Power Sources, 2003, 113: 62-71

14 Du Pasquier A, Plitz I, Menocal S, et al. A comparative study of Li- ion battery, supercapacitor and nonaqueous asymmetric hybrid devices for automotive applications. J Power Sources, 2003, 115: 171-178

15 Naoi $\mathrm{K}$, Ishimoto $\mathrm{S}$, Isobe $\mathrm{Y}$, et al. High-rate nano-crystalline $\mathrm{Li}_{4} \mathrm{Ti}_{5} \mathrm{O}_{12}$ attached on carbon nano-fibers for hybrid supercapacitors. J Power Sources, 2010, 195: 6250-6254

16 Stoller MD, Murali S, Quarles N, et al. Activated graphene as a cathode material for Li-ion hybrid supercapacitors. Phys Chem Chem Phys, 2012, 14: 3388-3391

17 Wang H, Jia G, Guo Y, et al. Atomic layer deposition of amorphous $\mathrm{TiO}_{2}$ on carbon nanotube networks and their superior $\mathrm{Li}$ and $\mathrm{Na}$ ion storage properties. Adv Mater Interfaces, 2016, 3: 1600375

18 Wang $\mathrm{H}, \mathrm{Xu} \mathrm{Z}$, Li Z, et al. Hybrid device employing threedimensional arrays of $\mathrm{MnO}$ in carbon nanosheets bridges batterysupercapacitor divide. Nano Lett, 2014, 14: 1987-1994

19 Karthikeyan K, Amaresh S, Lee SN, et al. Fluorine-doped $\mathrm{Fe}_{2} \mathrm{O}_{3}$ as high energy density electroactive material for hybrid supercapacitor applications. Chem Asian J, 2014, 9: 852-857

20 Kong $\mathrm{L}$, Zhang C, Wang J, et al. Free-standing $\mathrm{T}-\mathrm{Nb}_{2} \mathrm{O}_{5} /$ graphene composite papers with ultrahigh gravimetric/volumetric capacitance for Li-ion intercalation pseudocapacitor. ACS Nano, 2015, 9: $11200-11208$

21 Chen Z, Augustyn V, Wen J, et al. High-performance supercapacitors based on intertwined $\mathrm{CNT} / \mathrm{V}_{2} \mathrm{O}_{5}$ nanowire nanocomposites. Adv Mater, 2011, 23: 791-795

22 Li T, Beidaghi M, Xiao X, et al. Ethanol reduced molybdenum trioxide for Li-ion capacitors. Nano Energy, 2016, 26: 100-107

23 Wang Q, Wen Z, Li J. A hybrid supercapacitor fabricated with a carbon nanotube cathode and a $\mathrm{TiO}_{2}-\mathrm{B}$ nanowire anode. $\mathrm{Adv}$ Funct Mater, 2005, 16: 2141-2146

24 Lee $\mathrm{JH}$, Shin $\mathrm{WH}$, Ryou MH, et al. Functionalized graphene for high performance lithium ion capacitors. ChemSusChem, 2012, 5: 2328-2333

25 Banerjee A, Upadhyay KK, Puthusseri D, et al. MOF-derived crumpled-sheet-assembled perforated carbon cuboids as highly effective cathode active materials for ultra-high energy density Liion hybrid electrochemical capacitors (Li-HECs). Nanoscale, 2014, 6: 4387-4394

26 Zhu G, Chen T, Wang L, et al. High energy density hybrid lithiumion capacitor enabled by $\mathrm{Co}_{3} \mathrm{ZnC@N-doped} \mathrm{carbon} \mathrm{nanopolyhe-}$ dra anode and microporous carbon cathode. Energy Storage Mater, 2018, 14: 246-252

27 Chang J, Jin M, Yao F, et al. Asymmetric supercapacitors based on graphene $/ \mathrm{MnO}_{2}$ nanospheres and graphene/ $\mathrm{MoO}_{3}$ nanosheets with high energy density. Adv Funct Mater, 2013, 23: 5074-5083

28 Wang $\mathrm{Y}$, Gao Y, Shao J, et al. Ultrasmall $\mathrm{Fe}_{3} \mathrm{O}_{4}$ nanodots within Ndoped carbon frameworks from MOFs uniformly anchored on carbon nanowebs for boosting Li-ion storage. J Mater Chem A, 2018, 6: 3659-3666

29 Wang Y, Li Y, Qiu Z, et al. $\mathrm{Fe}_{3} \mathrm{O}_{4} @ \mathrm{Ti}_{3} \mathrm{C}_{2}$ MXene hybrids with ultrahigh volumetric capacity as an anode material for lithium-ion batteries. J Mater Chem A, 2018, 6: 11189-11197

30 Zhang WM, Wu XL, Hu JS, et al. Carbon coated $\mathrm{Fe}_{3} \mathrm{O}_{4}$ nanospindles as a superior anode material for lithium-ion batteries. Adv Funct Mater, 2008, 18: 3941-3946

31 Wang $\mathrm{C}$, Wang $\mathrm{J}$, Chen $\mathrm{H}$, et al. An interlayer nanostructure of $\mathrm{rGO} / \mathrm{Sn}_{2} \mathrm{Fe}-\mathrm{NRs}$ array/rGO with high capacity for lithium ion battery anodes. Sci China Mater, 2016, 59: 927-937

32 Wang $\mathrm{L}, \mathrm{Wu}$ J, Chen $\mathrm{Y}$, et al. Hollow nitrogen-doped $\mathrm{Fe}_{3} \mathrm{O}_{4} /$ carbon 
nanocages with hierarchical porosities as anode materials for lithium-ion batteries. Electrochim Acta, 2015, 186: 50-57

33 Geng Z, Li B, Liu H, et al. Oxygen-doped carbon host with enhanced bonding and electron attraction abilities for efficient and stable $\mathrm{SnO}_{2} /$ carbon composite battery anode. Sci China Mater, 2018, 61: 1067-1077

34 Chen T, Xu Y, Guo S, et al. Ternary heterostructural $\mathrm{Pt} / \mathrm{CN}_{x} / \mathrm{Ni}$ as a supercatalyst for oxygen reduction. iScience, 2019, 11: 388-397

35 Ding R, Zhang J, Qi J, et al. N-doped dual carbon-confined 3D architecture $\mathrm{rGO} / \mathrm{Fe}_{3} \mathrm{O}_{4} / \mathrm{AC}$ nanocomposite for high-performance lithium-ion batteries. ACS Appl Mater Interfaces, 2018, 10: 1347013478

36 Aravindan V, Gnanaraj J, Lee YS, et al. Insertion-type electrodes for nonaqueous Li-ion capacitors. Chem Rev, 2014, 114: 1161911635

37 Zhou J, Xu S, Ni L, et al. Iron oxide encapsulated in nitrogendoped carbon as high energy anode material for asymmetric supercapacitors. J Power Sources, 2019, 438: 227047

38 Hummers Jr. WS, Offeman RE. Preparation of graphitic oxide. J Am Chem Soc, 1958, 80: 1339

39 Suh $\mathrm{D}$, Lee $\mathrm{S}$, Mun $\mathrm{H}$, et al. Enhanced thermoelectric performance of $\mathrm{Bi}_{0.5} \mathrm{Sb}_{1.5} \mathrm{Te}_{3}$-expanded graphene composites by simultaneous modulation of electronic and thermal carrier transport. Nano Energy, 2015, 13: 67-76

40 Chatterjee S, Wang JW, Kuo WS, et al. Mechanical reinforcement and thermal conductivity in expanded graphene nanoplatelets reinforced epoxy composites. Chem Phys Lett, 2012, 531: 6-10

41 Yang GY, Shao S, Ke YH, et al. PtAu alloy nanoparticles supported on thermally expanded graphene oxide as a catalyst for the selective oxidation of glycerol. RSC Adv, 2015, 5: 37112-37118

42 Bartelmess J, Quinn SJ, Giordani S. Carbon nanomaterials: multifunctional agents for biomedical fluorescence and Raman imaging. Chem Soc Rev, 2015, 44: 4672-4698

43 Zhu J, Xu Y, Zhang Y, et al. Porous and high electronic conductivity nitrogen-doped nano-sheet carbon derived from polypyrrole for high-power supercapacitors. Carbon, 2016, 107: 638645

44 Tang X, Jia R, Zhai T, et al. Hierarchical $\mathrm{Fe}_{3} \mathrm{O}_{4} @ \mathrm{Fe}_{2} \mathrm{O}_{3}$ core-shell nanorod arrays as high-performance anodes for asymmetric supercapacitors. ACS Appl Mater Interfaces, 2015, 7: 27518-27525

45 Ma Y, Huang J, Lin L, et al. Self-assembly synthesis of 3D graphene-encapsulated hierarchical $\mathrm{Fe}_{3} \mathrm{O}_{4}$ nano-flower architecture with high lithium storage capacity and excellent rate capability. J Power Sources, 2017, 365: 98-108

46 Zhao J, Lai H, Lyu Z, et al. Hydrophilic hierarchical nitrogendoped carbon nanocages for ultrahigh supercapacitive performance. Adv Mater, 2015, 27: 3541-3545

47 Li Z, Xu Z, Tan X, et al. Mesoporous nitrogen-rich carbons derived from protein for ultra-high capacity battery anodes and supercapacitors. Energy Environ Sci, 2013, 6: 871

48 Yang M, Zhou Z. Recent breakthroughs in supercapacitors boosted by nitrogen-rich porous carbon materials. Adv Sci, 2017, 4: 1600408

49 Hao L, Li X, Zhi L. Carbonaceous electrode materials for supercapacitors. Adv Mater, 2013, 25: 3899-3904

$50 \mathrm{He} \mathrm{C}, \mathrm{Wu} \mathrm{S}$, Zhao $\mathrm{N}$, et al. Carbon-encapsulated $\mathrm{Fe}_{3} \mathrm{O}_{4}$ nanoparticles as a high-rate lithium ion battery anode material. ACS Nano, 2013, 7: 4459-4469

51 Qin $\mathrm{X}$, Zhang $\mathrm{H}$, Wu J, et al. $\mathrm{Fe}_{3} \mathrm{O}_{4}$ nanoparticles encapsulated in electrospun porous carbon fibers with a compact shell as high- performance anode for lithium ion batteries. Carbon, 2015, 87: 347-356

52 Chen $\mathrm{M}$, Shen $\mathrm{X}$, Chen $\mathrm{K}$, et al. Nitrogen-doped mesoporous carbon-encapsulation urchin-like $\mathrm{Fe}_{3} \mathrm{O}_{4}$ as anode materials for high performance Li-ions batteries. Electrochim Acta, 2016, 195: 94-105

53 Okubo M, Hosono E, Kim J, et al. Nanosize effect on high-rate Liion intercalation in $\mathrm{LiCoO}_{2}$ electrode. J Am Chem Soc, 2007, 129: 7444-7452

54 Tie D, Huang S, Wang J, et al. Hybrid energy storage devices: advanced electrode materials and matching principles. Energy Storage Mater, 2019, 21: 22-40

55 Chao D, Liang $\mathrm{P}$, Chen $\mathrm{Z}$, et al. Pseudocapacitive Na-ion storage boosts high rate and areal capacity of self-branched 2D layered metal chalcogenide nanoarrays. ACS Nano, 2016, 10: 10211-10219

56 Lesel BK, Ko JS, Dunn B, et al. Mesoporous $\mathrm{Li}_{x} \mathrm{Mn}_{2} \mathrm{O}_{4}$ thin film cathodes for lithium-ion pseudocapacitors. ACS Nano, 2016, 10: $7572-7581$

$57 \mathrm{Xu} \mathrm{X}$, Liu J, Liu Z, et al. Robust pitaya-structured pyrite as high energy density cathode for high-rate lithium batteries. ACS Nano, 2017, 11: 9033-9040

58 Huang M, Chen C, Wu S, et al. Remarkable high-temperature Listorage performance of few-layer graphene-anchored $\mathrm{Fe}_{3} \mathrm{O}_{4}$ nanocomposites as an anode. J Mater Chem A, 2017, 5: 23035-23042

59 Wang $\mathrm{Y}$, Jin $\mathrm{Y}$, Zhao $\mathrm{C}$, et al. $\mathrm{Fe}_{3} \mathrm{O}_{4}$ nanoparticle/graphene aerogel composite with enhanced lithium storage performance. Appl Surf Sci, 2018, 458: 1035-1042

60 Owusu KA, Qu L, Li J, et al. Low-crystalline iron oxide hydroxide nanoparticle anode for high-performance supercapacitors. Nat Commun, 2017, 8: 14264

61 Alam SN, Sharma N, Kumar L. Synthesis of graphene oxide (GO) by modified Hummers method and its thermal reduction to obtain reduced graphene oxide $(\mathrm{rGO})^{*}$. Graphene, 2017, 06: 1-18

62 Zhou J, Chen N, Ge Y, et al. Flexible all-solid-state micro-supercapacitor based on Ni fiber electrode coated with $\mathrm{MnO}_{2}$ and reduced graphene oxide via electrochemical deposition. Sci China Mater, 2018, 61: 243-253

63 Yang MH, Lee KG, Lee SJ, et al. Three-dimensional expanded graphene-metal oxide film via solid-state microwave irradiation for aqueous asymmetric supercapacitors. ACS Appl Mater Interfaces, 2015, 7: 22364-22371

64 Liu W, Li J, Feng K, et al. Advanced Li-ion hybrid supercapacitors based on 3D graphene-foam composites. ACS Appl Mater Interfaces, 2016, 8: 25941-25953

65 Patil SJ, Kim JH, Lee DW. Graphene-nanosheet wrapped cobalt sulphide as a binder free hybrid electrode for asymmetric solidstate supercapacitor. J Power Sources, 2017, 342: 652-665

66 Chen Z, Yuan Y, Zhou H, et al. 3D nanocomposite architectures from carbon-nanotube-threaded nanocrystals for high-performance electrochemical energy storage. Adv Mater, 2014, 26: 339345

67 Come J, Naguib M, Rozier P, et al. A non-aqueous asymmetric cell with a $\mathrm{Ti}_{2} \mathrm{C}$-based two-dimensional negative electrode. J Electrochem Soc, 2012, 159: A1368-A1373

68 Li M, Pan F, Choo ESG, et al. Designed construction of a graphene and iron oxide freestanding electrode with enhanced flexible energy-storage performance. ACS Appl Mater Interfaces, 2016, 8: 6972-6981

Acknowledgements The authors appreciate the financial support of 
the National Natural Science Foundation of China (21773116), the Specialized Research Fund for the Doctoral Program of Higher Education (SRFDP, 20130091110010), the Natural Science Foundation of Jiangsu Province (BK2011438), the National Science Fund for Talent Training in Basic Science (J1103310), the Modern Analysis Center of Nanjing University and Program B for Outstanding PhD candidate of Nanjing University.

Author contributions Zhou J and Hou W conceived the idea. Zhou J and $\mathrm{Xu} \mathrm{S}$ carried out the sample synthesis, characterization and performance measurements and wrote the manuscript. Kang Q, Ni L, Chen N, Li X, Peng L, Wang X, Guo X and Ding W participated in the general discussion. Lu C helped with XPS measurement. Wang X helped with BET measurements. Zhou J edited the manuscript and Hou W revised the manuscript.

Conflict of interest The authors declare no conflict of interest.

Supplementary information

Supporting data are available in the online version of the paper.

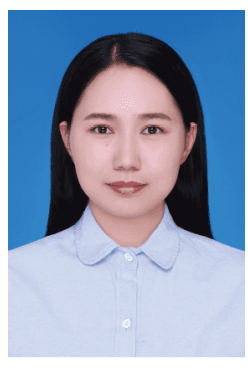

Jinhua Zhou obtained her MSc degree from Nanjing University of Posts \& Telecommunications in 2016. Currently, she is pursuing her PhD degree under the supervision of Prof. Wenhua Hou at Nanjing University. Her research is mainly focused on the synthesis of 2D layered transition metal oxide nanomaterials, and their application for energy conversion and storage devices.

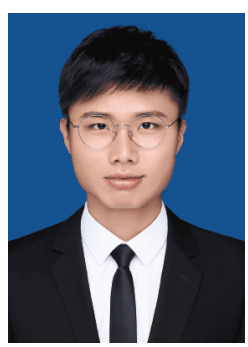

Shuchi Xu received his BSc degree in chemistry from the School of Chemistry and Chemical Engineering, Nanjing University in 2019. He worked with Prof. Wenhua Hou at Nanjing University in the last two years, focusing on the application of transition metal oxide nanomaterials as electrode.

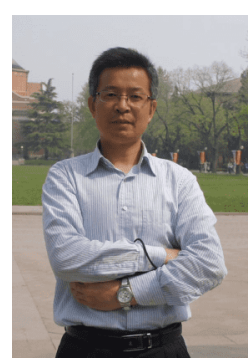

Wenhua Hou is a professor in the School of Chemistry and Chemical Engineering at Nanjing University. He received his BSc (1985) and $\mathrm{PhD}$ (1993) degrees in chemistry from Nanjing University. He once worked as visiting scholar at the State University of New York at Albany and the University of California, San Diego. His current research interests include the synthesis of $2 \mathrm{D}$ layered nanomaterials for potocatalysis and energy conversion and storage.

\section{核壳结构 $\mathrm{Fe}_{3} \mathrm{O}_{4} @ \mathrm{NC}$ 复合材料的储锂性能研究及 锂离子电容器构建}

周锦华 ${ }^{1 \dagger}$, 徐舒迟 ${ }^{1 \dagger}$, 康琪 ${ }^{2}$, 倪璐 $^{1}$, 陈宁娜 ${ }^{1}$, 李小阁 ${ }^{1}$, 陆春良 ${ }^{3}$, 王喜章 ${ }^{1}$, 彭路明 ${ }^{1}$, 郭学锋 ${ }^{1}, 丁^{2}$ 维平 ${ }^{1}$, 侯文华 ${ }^{{ }^{*}}$

摘要 锂离子电容器继承了超级电容器高功率性能和锂离子电池 高能量密度两者的优点. 然而, 高电化学性能电极材料的短缺以及 正负电极材料动力学的不匹配是构筑高能量/高功率密度锂离子电 池遇到的最大挑战. 我们通过简单的溶液组装和煅烧法得到了具 有核壳结构的 $\mathrm{Fe}_{3} \mathrm{O}_{4} @ \mathrm{NC}$ 复合材料. 首先, 研究了不同热解温度得 到的 $\mathrm{Fe}_{3} \mathrm{O}_{4} @ \mathrm{NC}$ 样品的储锂性能. 结构单元纳米化和丰富的微孔使 得 $\mathrm{Fe}_{3} \mathrm{O}_{4} @ \mathrm{NC}-700$ 具有大比表面积, 同时暴露出更多的活性位点, 缩 短了离子传输路径, 表现出特殊的赝电容行为, 从而显著提高了储 锂动力学. 除此之外, $\mathrm{N}$-掺杂的碳壳提供了较高的电子导电性并保 证了在循环测试中的结构完整性. 以 $\mathrm{Fe}_{3} \mathrm{O}_{4} @ \mathrm{NC}-700$ 为负极, 膨胀石 墨烯EGN为正极, $1 \mathrm{~mol} \mathrm{~L}^{-1} \mathrm{LiPF}_{6}$ 为电解液, 组装成锂离子电容器. 受益于正负电极相配的动力学以及 $\mathrm{Fe}_{3} \mathrm{O}_{4} @ \mathrm{NC}-700$ 和EGN两者的 协同优势, $\mathrm{Fe}_{3} \mathrm{O}_{4} @ \mathrm{NC}-700 / / \mathrm{EGN}$ 杂化离子电容器获得了较宽的工 作电压窗口 (1.0-4.5 V), 比能量最高可达 $137 \mathrm{~W} \mathrm{~h} \mathrm{~kg}^{-1}$, 比功率最高 可达 $8.2 \mathrm{~kW} \mathrm{~kg}^{-1}$, 且循环稳定性出色. 本工作可为下一代兼具高比 能量和高比功率的新型混合能源存储系统的设计提供启示. 